\title{
Interests of Organic Food Consumers
}

\author{
Anna CIERNIAK-EMERYCH ${ }^{1}$, Szymon DZIUBA ${ }^{1}$, Ivan SOUKAL $^{2}$, Małgorzta \\ JAROSSOVA $^{3}$ \\ ${ }^{1}$ University of Economics in Wroclaw, Wroclaw, Poland \\ aemerych@wp.pl; szymon.dziuba@ue.wroc.pl \\ ${ }^{2}$ University of Hradec Králové, Hradec Králové, Czech Republic \\ ivan. soukal@uhk.cz \\ ${ }^{3}$ University of Economics in Bratislava, Bratislava, Slovakia \\ malgorzata.jarossova@euba.sk
}

\begin{abstract}
Perception of the enterprise from the standpoint of interests (expectations) of consumers (customers) is socially and economically justifiable. It concerns all the enterprises, including, perhaps especially, those that produce organic foods. Over the last years, people have started to more and more often care for their health and for what they eat. Organic food production has raised the standards of quality for conventional methods and has often demonstrated its superiority in both product quality and other benefits of organic food production. Therefore, the aim of the study was to collect information about an understanding of the concept of organic food by consumers and to identify expectations (interests) of consumers. Analysis of the above problems was based on the empirical pilot research performed by the authors and the literature survey. The study outlines a direction a further topic survey could follow such as a consumer ability to identify an organic food, explain the term or state a frequency of buying organic food products.
\end{abstract}

Keywords: Interests, Consumers, Organic Food

\section{Introduction}

There is a widespread belief in the related literature that contemporary enterprises have to be aware that they operate in a specific environment, whereas their relations with specific groups of stakeholders have an effect on their reputation, long-term results and market position [8]. As indicated by M. Crozier [2, p. 20], one cannot forget the necessity of social reality, including the legitimacy of listening to the stakeholders, who are the most important to the enterprise. Therefore, it is becoming important to ensure a comprehensive identification of the stakeholders, their role with respect to the enterprise, with a particular focus on recognition of their expectations.

Among the stakeholders connected with the enterprise are internal stakeholders (insiders), such as owners, employed managers and employees, and external stakeholders (outsiders). The outsiders include in particular customers, suppliers, partners, financial institutions, insurance firms, local governments, and potential (for 
a specific organization) employees [1, p. 14-15]. Under conditions of the constantly increasing competitiveness, the particular focus, as it seems, besides insiders, should be on customers and recognize and meeting their expectations.

Customers expect not only a specific value (e.g. quality, health values), but they also transfer a specific value (e.g. cash, loyalty, trust) in exchange. Relationships of the customers with the enterprise should also be characterized by trust, loyalty, credibility, and friendship, which they can "bestow" on the enterprise in expectation of reciprocity [9].

Creating such persistent ties between enterprises and customers seem to be especially important to producers and food consumers. It is worth noting that for several recent years, the problems of organic foods has been addressed in both business practice and scientific studies. It is also remarkable that organic foods are foods from organic farming and produced by means of organic agriculture methodologies in a clean and uncontaminated environment [4, p. 28].

Organic farming has demonstrated its superiority over the conventional food production methods in both product quality and other benefits of organic food production. It should be emphasized that organic food, which is high-quality food, is only the products with specific symbols and from farms or organic production.

With this definition, the aim of the study was, on the one hand, to obtain information about an understanding of the concept of organic food by customers, and on the other hand, identification of the expectations (interests) of consumers (customers) concerning the organic food products. The attempts to achieve this aim were supported by the presentation of the basic information about the specific nature of organic food and its manufacturing, which represented the aim of the theoretical part of the study.

\section{Methodological aspects of examinations and literature overview}

\section{$2.1 \quad$ Research methodology}

With consideration for the above problems, the study involved:

- an overview of the literature, legal acts, and published reports,

- a diagnostic survey with pilot character, concerning the interest of the students of the last year of master's course in starting the business activity connected with selfemployment.

Empirical studies were conducted in the third quarter 2017, whereas they concerned 64 respondents, of whom $60 \%$ were women and $40 \%$ were men. Therefore, the dominant sex was women, aged 21 to 26 years. The respondent inclusion criterion was their consent for participation in the study. Most respondents lived in the region of the Lower Silesia (Poland).

The study used the survey questionnaire containing the closed-end questions, with several options of answers, and open questions. The survey was of anonymous and 
confidential character. The analysis concerned the list of 15 interests, preceded by the questions that allowed for assessment of the knowledge of respondents concerning organic foods and their specific nature. The proposed set of interests was developed based on the literature survey and authors' own observations. Furthermore, the respondents had an option of supplementing this list with the interests which were not mentioned.

The respondents were asked to assess each of the proposed interests from their own standpoint while having the choice of the following answers: very important, rather important, neither important nor unimportant, rather unimportant or unimportant at all. The results presented below refer only to the expectations which were assessed as very important.

The study was preceded by the free-form interviews with the respondents who expressed their consent to participate in the interview (36 people). The in-depth interview (IDI) described by S. Kaczmarczyk was used, which is a direct method of the primary survey, where a respondent is an active object of the measurement and a direct communication between people subjected to the measurement and those who make measurements occurs (conversation) [7, p. 252 and further].

The presented results cannot be considered as statistically significant but they should be approached in the categories of initial recognition of the correctness of the adopted research assumptions and the basis for the formulation of further research goals.

\subsection{Research Organic food and interests of consumers in light of literature}

R. B. Tucker argues that enterprises, in order to survive in the turbulent environment, must respond to changes through continuing implementation of innovative solutions and prediction of new emerging needs and expectations of customers (consumers), especially by offering opportunities for meeting them [13]. From this standpoint, the category of customer satisfaction is becoming important, especially for the economic outcomes and especially the social effects of the enterprise functioning. The satisfaction is hardly measurable phenomenon since it concerns individual needs and expectations of customers which are much varied. Therefore, the problem of strategic importance is to recognize these expectations that are conducive to the achievement of the indicated satisfaction.

With this background, the consumers are more and more oriented towards care for the responsible consumption and the related activities which are conducive not only to the care for the environment, conditions of production of the products offered but also the consequences of their use. The latter concerns especially the responsible consumption of food products.

In this context, it is worth emphasizing the fact that over the last years, people have started to think more about their health and pay more attention to what they eat. Consequently, the number of organic food consumers is constantly rising. Organic farms and shops that sell these products are also developing. 
The definition of the Food Code published by the Food and Agriculture Organization/ World Health Organization (FAO/WHO) says that organic foods are those produced by farms that use organic systems harmonized with the environment. Therefore, the foods are produced based on the principles that organic farming organizations use to award special trademarks. In order for a product to be considered as organic, certain prerequisites have to be met, contained in the Basic Standards for Organic Production and Processing according to the International Federation of Organic Agriculture Movements (IFOAM). The first version of these standards was published in 1982. The document contained the principles of production, processing, storage, labeling and placement on the market of foods. In English language publications, this type of food is termed organic food [11, p. 80].

The organic foods are characterized by at least $95 \%$ of ingredients produced using organic farming methods or fully organic (organic raw materials) or those with at least $70 \%$ of such ingredients, with $30 \%$ permissible from processing using the organic processing technologies. Organic foods can be divided into three categories according to the content of organic ingredients [3, p. 9-21;28]:

- Category I: amounts of organic ingredients of over 95\%; only these products can be labeled as organic and regarded as organic products,

- Category II: amounts of organic ingredients range from 50 to $95 \%$, with these products termed partially organic,

- Category III: a content of organic ingredients below 50\%; these products are not qualified as organic and are termed non-organic.

The current legal pillar concerning organic farming in Poland is the Act as of 5 December 2014 on the amendment of the act on organic farming [10].

The particular focus should be on the principles that concern processing of the organic foods. Producers of such foods are obliged to produce foods using organic agricultural components except for the case of unavailability of the component of "organic" quality in the market. It is recommended that food additives, auxiliary substances, microelements and non-organic components that perform sensory and technological functions should be limited to the minimum level and used only if technology requires using them or the product is designed to be used for specific food purposes. Organic food producers are obliged to carefully process foods using biological, physical and mechanical methods. It is forbidden to use GMOs and ionizing radiation to process foods or raw materials used as food ingredients [12].

Organic products can be recognized by their labels, with words organic, eco or bio, the EU organic logo (Euro Leaf) and the certification authority number. Only this product marking provides the guarantee of its organic origins. Figure 1 presents the graphical symbol of the Euro Leaf. 


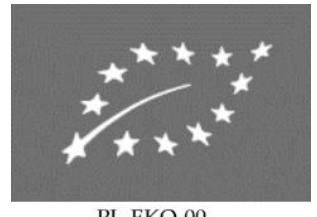

PL-EKO-00

Fig. 1. The EU's organic farming logo [3].

In 2012, Poland was among the leading countries of the European Union in terms of the number of ecological countries and the surface of the agricultural land for organic farming. However, in terms of the percentage of land for organic farming in the total agricultural land, Poland, compared to other EU countries, was below the average. With this background, Poland's immediate neighbouring countries (Czech Republic and Slovakia) were much better [14, p. 160-165].

It is worth showing the example of one of the pioneers of organic food in Czech Republic, the limited liability company "PRO-BIO, obchodní společnost s.r.o.", which was founded in 1992. The company has an ecological certificate (KEZ, ww.kez.cz) and also meets international quality standards (IFS) which solve the problems of security and quality of food products. The main objective of PRO-BIO is processing of cereals and food wholesale (ca. 1,200 products offered). The company also produces seeds. PRO-BIO is one of the biggest companies in the Czech Republic, dealing with production and sales of organic foods [5]. It should also be emphasized that the enterprise cooperates with Polish farmers who produce organic foods.

With this background, the information contained in the report "Organic food in Poland 2017" prepared by IMAS International sp. z o.o. is especially interesting. Among other things, the report says that ,, The market is in the growth phase, which is also forecast for the years to come, the industry is picking up, the barriers of product availability are being overcome, and the organic food products are reaching not only shelves of specialized shops but also local shops or supermarkets. Consumers of organic foods are motivated for purchasing them, have substantial knowledge of organic foods and their effects on health. ..."[13].

With this in mind, the following part of the study presents the results of the pilot research concerning the knowledge of the idea of organic food and expectations connected with this type of food products in a group of respondents.

\section{Organic food consumer interests: presentation of chosen aspects of empirical studies}

Organic products are characterized by a specific character, including individual smell and specific production methods. This ensures that the producers can be more attractive in the market. However, in order to make it possible, the producers should, apart from other variables, such as legal regulations, take into account the interests 
(expectations) of customers. Especially important is knowledge of customers about the characteristics of organic foods.

The empirical study showed that $85 \%$ of 64 respondents were unable to identify the term organic food. It is also interesting that $95 \%$ of the same respondents declared that they knew how to identify organic foods in the shops. The respondents properly described the symbols that certify the organic foods.

The study also showed that $18 \%$ of the respondents declared buying organic foods at least once a week. Other people in this group did not buy organic foods since they found it expensive and difficult to find.

Using the results of the study, the Tab. 1 presents the interests (expectations) which are found as very important by the respondents who represented consumers of organic foods.

Table 1. Interests of organic food consumers.

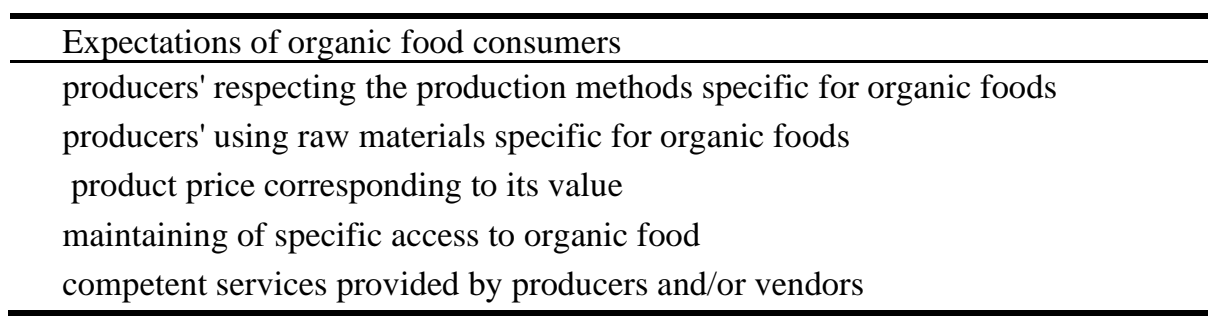

With reference to the interests preferred by consumers (see Tab. 1), it is interesting that the consumers ranked the problems of care for raw materials and production methods as very important.

As results from in-depth interviews over the respondents who gave consent for the interview, the people who buy organic foods are guided by health concerns, taste, and tendencies for eating healthy foods. When selecting the shop with organic foods, the important factor is consumers' trust to the supplier (98\%). The respondents indicated that they prefer small atmospheric shops or street markets, where they can familiarize with food news and know that organic food is original and not forged. They also often know the concrete organic farm that produces the specific product. The symbols only confirm product quality. The respondents demonstrated that they had experienced inconsistency in these terms. It happened that they had to deal with dishonest producers. Several respondents indicated that these situations had affected their perception of the value of organic foods.

Among the group of expectations considered by consumers as very important, there was the statement concerning "maintaining of specific access to organic food." The in-depth interviews showed that the respondents, who were asked to consider the above cases of the dishonesty of producers or vendors, expressed the views that the access to the organic products should be somehow limited and the opportunities of selling them should be connected with obtaining specific certificates. The need was emphasized for the knowledge of people who sell organic food concerning food characteristics, especially health values. Consumers choose organic foods since they 
are aware that this type of food is less chemically contaminated. They are afraid of the unfavourable effect of residue substances contained in the conventional foods as a consequence of using pesticides, antibiotics, and hormones.

All the respondents who declared buying organic food found that food appearance is unimportant (this food typically looks unattractive). The health function of the food is what matters to buyers. These people also indicated the necessity of using biodegradable packages.

\section{Conclusions}

Recognizing the foreground role of the external stakeholders requires the focus on their interests (expectations), which should be connected especially with satisfaction, quality, and product reliability.

This was also reflected in the above-presented pilot research concerning the interests of producers and consumers of organic foods. The particular task of producers is to create the picture of the enterprise for the consumer. Therefore, the consumers are especially interested in respecting formally and informally defined procedures, using specific raw materials, production techniques and names of products.

As already mentioned, the results of the empirical survey presented in this study concerned a pilot study. These results cannot be found significant in statistical terms. Nevertheless, the opinions of both producers and customers seem to be important and interesting. Therefore, it is worth verifying them in a bigger, representative group of respondents. With reference to the examples of the Poland's neighbouring countries indicated in the study (Czech Republic and Slovakia) and their experiences concerning the organic foods, it seems justified to perform such studies not only in Poland but to include the examinations of the respondents and consumers from the Czech Republic and Slovakia. Furthermore, it would be worth examining the producers of organic foods, which, especially in the context of forging foodstuffs, should be important. Bearing this in mind, the problems presented in the study should be further explored and subjected to public discussions.

\section{References}

1. Bielski, M.: Podstawy teorii organizacji i zarządzania. C.H.Beck, Warszawa (2002).

2. Crozier M.: Enterprise under surveillance. How to learn post-industrial management. PWE, Warsaw (1993).

3. Department of Commercial Inspection of the Office for Competition and Consumer Protection: Informacja z kontroli jakości i prawidłowości oznakowania produktów rolnictwa ekologicznego, https://www.uokik.gov.pl/download.php?plik=15275, last accessed 2017/10/15

4. Dziuba, S. Szołtysek, K.: General comments to organic farming, guide for laboratory classes in ecotrophology, Publishing House of the University of Economics in Wrocław, Poland (2012). 
5. Eko Arka: PRO-BIO pioneers of organic food in Czech Republic, ekoarka.com.pl/pro-biopionierzy-eko-zywnosci-w-czechach/, last accessed 2017/10/13.

6. IMAS International: Organic foods in Poland $2017 \mathrm{http}: / /$ imas.pl/blog/raport-zywnoscekologiczna-w-polsce-2017-juz-do-pobrania/, last accessed 2017/10/15.

7. Kaczmarczyk, S.: Badania marketingowe. Metody i techniki. PWE, Warsaw (1999).

8. Mendel T.: Partycypacja w zarządzaniu współczesnymi organizacjami. Wydawnictwo Akademii Ekonomicznej, Poznań (2001).

9. Otto, J.: Marketing relacji. C.H.Beck, Warsaw (2004).

10. Parliament of the Polish Republic: The act of 5 December 2014 amending the act on organic farming. Journal of Laws 2015, Pos. 55.

11. Pilarski, S., Grzybowska, M., Brzeziński, M.: Rynek żywności ekologicznej, monografie i rozprawy. Wyd. Wyższej Szkoły Agrobiznesu w Łomży, Łomża (2003).

12. Sołtysiak, U.: Żywność ekologiczna - zasady produkcji i kontroli. Przemysł Fermentacyjny i Owocowo-Warzywny 52(1), 2 (2008).

13. Tucker, R.B. : Zarządzanie z przyszłością. Pruszyński i S-ka, Warsaw (1998).

14. Wasilik, K.: Rolnictwo ekologiczne i rynek eko-produktów w Polsce na tle innych krajów europejskich. Handel Wewnętrzny 3(350), 160-165 (2014). 